\title{
Генноинженерная бuотехнология
}

УДК $575.24: 582.282 .23$

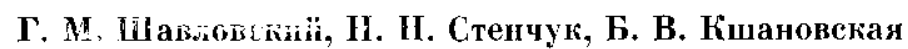

\section{ВЈИЯНИЕ РЕГУЛЯТОРНОЙ МУТАЦИИ В ЈIКУСЕ RIB 1 НА БИОСИНТЕЗ РИБОФЛАВИНА y PICHIA GUILLIERMONDII}

Селекционирован мутант rib1-86 P. guilliermondii, у которого рибофлавинзависимость супрессируется регуляторной мутащией тіb81, но не таковой тів80. Двойной мутант rib1-86 rib81 характеризуется низким ировнем активности ГТФ-циклогидролазы, синтез которой слабо регулируется железом. По-видимому, мутация тіb1-86 лежит в промоторной области гена RIBI, кодирующего ГTФ-циклогидролазу.

Введение. Биосинтез рибофлавина (РФ) у дрожжей $P$. guilliermondii регулируется двумя генами негативного типа действия $R I B 80, R I B 81$ и двумя - позитивного - RIB83, RIB84 [1-3]. Дефицит железа в среде, а также мутации rib80 и rib81 вызывают дерепрессию биосинтеза большинства ферментов флавиногенеза и, как следствие, сверхсинтез РФ дрожжами. Мутанты rib83 и rib84 неспособны к сверхсинтезу этогс витамина в условиях дефицита железа.

До сих гор не удалось селекционировать мутанты дрожжей с поврежденными промоторными зонами структурных генов биосинтеза РФ. На основе работ по изучению регуляции биосинтеза изо-1-цитохрома $c$ и других дрожжевых ферментов известно, что в этих зонах находится несколько локусов (UAS, TA'TA, I), являющихся акцепторами различных регуляторных сигналов и эффективно влияющих на уровень экспрессии структурного гена [4]. Поэтому выделение мутантов с поврежденными элементами промотора является важной предпосылкой создания модели регуляции экспрессии исследуемого гена.

В настоящем сообщении приводятся данные о выдслении муганта rib1-86 P. guilliermondii с нарушенной регуляцией флавиногенеза, у которого, по-видимому, повреждена промоторная зона гена $R I B 1$, кодирующего ГТФ-циклогидролазу.

Материалы и методы. Генотипы использованих в работе штаммов представлены в таблице. Культуры дрожжей выращивали в синтетической модифицированной среде Беркгольдера. Состав среды и методы гснетического аиализа описаны ранее [5]. Среду от металлов очищали с помогцьо 8-оксихинолина [6]. Биомассу дрожжей определяли турбидиметритески на фогоэлектроколориметре ФЭК-56М (кювета 3 мм, светофильтр № 6). Концентрацию РФ в среде измеряли флюорометритески на прнборе ЭФ-ЗМ. Активность ГТФ-циклогидролазы и РФ-синтазы определяли, испольуя извсстиыс мстоды $[7,8]$. [3 таблице представлены средние величины, полученные в двух - трсх эксперимснтах.

Результаты и обсуждение. Для выдслсния новых мугантов с :ефектом позитивного контроля биосинтеза РФ применяли в качестве исходного пітамм $S 131 / 6$, который из-за наличия у него мутации rib81 способен к сверхсинтезг РФ в условиях оптимального для роста обеспеэения желгзом (см. таблицу). Клоны с резко сииженной интенсивноC) Г. М. ШАВЛОВСКНИ, Н. Н. СТЕНЧУК, Б. В. КШАНОВСКАЯ, 1991 
Флавиногенез, актияность ГТФ-циклогидролазы и РФ-синтазы регуляторнвх мутантов $P$. guilliermondii

\begin{tabular}{|c|c|c|c|c|c|}
\hline \multirow{2}{*}{ ШIтамM } & \multirow{2}{*}{ Генотип } & \multirow{2}{*}{$\begin{array}{c}\text { Концентра- } \\
\text { ция железа } \\
\text { в среде, } \\
\text { мг/л }\end{array}$} & \multirow{2}{*}{$\begin{array}{l}\text { РФ среды, } \\
\text { мг/r клеток } \\
\cdots . . j\end{array}$} & \multicolumn{2}{|c|}{ 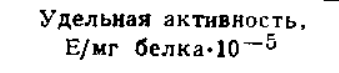 } \\
\hline & & & & $\begin{array}{c}\text { ГТФ-цикло- } \\
\text { гндролаза }\end{array}$ & РФ-синтаза \\
\hline $5 I 31 ; 6$ & rib81 met-1 & $\begin{array}{l}0,2 \\
0,01\end{array}$ & $\begin{array}{l}1,1 \\
25,6\end{array}$ & $\begin{array}{l}11,0 \\
13,8\end{array}$ & - \\
\hline$L V 124$ & ribl-86 rib81 met -1 & $\begin{array}{l}0,2 \\
0,01\end{array}$ & $\begin{array}{l}0,02 \\
0,01\end{array}$ & $\begin{array}{l}0,4 \\
0,2\end{array}$ & $\begin{array}{r}9,9 \\
35,8\end{array}$ \\
\hline$L V 166$ & $\begin{array}{l}\text { ribl-86 ade } 2-19 \\
\text { met }-1\end{array}$ & $\begin{array}{l}0,2 \\
0,01\end{array}$ & $\rightarrow$ & $\begin{array}{l}0,1 \\
0,1\end{array}$ & $\begin{array}{r}3,0 \\
14,8\end{array}$ \\
\hline LVI66-8 & $\begin{array}{l}\text { rib } 1.86 \text { ribs1 } \\
\text { ade } 2-19 \text { met }-1\end{array}$ & $\begin{array}{l}0,2 \\
0,01\end{array}$ & $\begin{array}{l}0,02 \\
0,17\end{array}$ & $\begin{array}{l}0,2 \\
0,1\end{array}$ & $\begin{array}{l}11,5 \\
16,3\end{array}$ \\
\hline$L V 172$ & $\begin{array}{l}\text { rib1-86 rib80 rib81 } \\
\text { ade } 2-19 \text { met }-1\end{array}$ & $\begin{array}{l}0,2 \\
0,01\end{array}$ & $\begin{array}{l}0,03 \\
0,09\end{array}$ & - & - \\
\hline ATCC9058 & Дикий тип & $\begin{array}{l}0,2 \\
0,01\end{array}$ & $\begin{array}{l}0,10 \\
14,4\end{array}$ & $\begin{array}{r}2,7 \\
14,7\end{array}$ & $\begin{array}{r}2,0 \\
19,8\end{array}$ \\
\hline
\end{tabular}

П римечание. ade2, met-мутация, обусловливающие адснин- и метионинзависимость соответственно; знак «-»-не определяли.

стью биосинтеза РФ отбирали визуально после подращивания мутагенизированной $\mathrm{N}$-метил- $\mathrm{N}^{\prime}$-нитро- $\mathrm{N}^{\prime}$-нитрозогуанидином культуры этого штамма на агаризованной среде. Последующее выращивание их в дефицитной по железу жидкой среде $(0,01 \mathrm{mr} \mathrm{Fe} / л)$ позволило отобрать 35 мутантов, неспособных к сверхсинтезу РФ в этих условиях. В коллекции полученных мутантов оказался один (LV124), у которого это свойство вызвано мутацией, комплементирующей идентифицированные ранее мутации rib83 и rib84. Очевидно, неспособность к сверхсинтезу РФ штамма LV124 вызвана нарушением механизма дерепрессии сннтеза ферментов флавиногенеза. Определение активности ГТФ-циклогидролазы и РФ-синтазы показало (см. таблицу), что в условиях дефицита железа дерепрессируется только последняя из них.

Для разделения новой регуляторной мутации и мутации rib81 штамм LV 124 скрестили со штаммом дикого типа и проанализировали характер мейотического расщепления у полученного гибрида. Неожиданным было то, что среди сегрегантов обнаружены не только таковые с фенотипами шламмов $S 131 / 6$ и $L V 124$, но и РФ-зависимые ауксотрофы. Результаты гибридизации таких РФ-зависимых сегрегантов с РФзависимыми мутантами генотипов ribl-rib7, дефектных по соответствующим структурным генам биосинтеза РФ [5], показали, что новая мутация комплементирует с мутациями во всех структурных генах, кроме ribl, и, следовательно, локализована в гене $R I B I$, кодируюшем синтез ГТФ-циклогидролазы; она обозначена нами rib1-86.

Штамм $L V 166$ (один из сегрегантов), обладающий этой мутацией, является полным РФ-ауксотрофом. Оптимальной для его роста концентрацией РФ является $200 \mathrm{Mкг} / \mathrm{мл}$, что характерно для РФ-зависимых ауксотрофов P. guilliermondii [5]. При длительной (более 5 сут) инкубации клеток этого штамма в среде без РФ в ряде случаев наблюдали увеличение оптической плотности культуры только за счет размножения прототрофных ревертантов, но не мутантных клеток rib1-86. Активность ГТФ-циклогидролазы у штамма $L V 166$ не обнаруживается даже при росте в условиях дефицита железа, в то время как синтез РФ-синтазы репрессирован в условиях оптимального для роста обеспечения клеток железом и дерепрессирован при его дефиците в среде. Таким образом, штамм LV 166 не является брадитрофным (leaky) мутантом по гену RIBI.

РФ-независимость штамма $L V 124$ свидетельствует о том, что мута- 
ция rib81 супрессирует таковую rib1-86. Дополнительные доказательства в пользу этого вывода получены с помощью анализа свойств 128 слонтанных РФ-независимых үевертантов штамма LVI66. Результаты комплементационного анализа показали, что 126 из них являются двойными мутанами rib81 rib1-86. Свойства одного нз них (LV 166-8) прецставлены в таблице. Характерным для него, как и для шттамма LV 124, является неспособность к сверхсинтезу РФ в условиях дефицита желеsa, ннзкий уровснь активности ГТФ-циклогидролазы и дерепрессия синтеза РФ-силтазы.

Дерелрессию биосинтеза ферментов флавиногенеза у $P$. guillicrmondii вызываст такіке мутация rib80 [1]. Сконструированный нами двойнов̈ мутант rib80 rib1-86 является РФ-зависимым ауксотрофом даже в условиях пефицита железа. Следовательно, мутация rib80 не супрессирует таковую rib $1-86$.

РФ-зависимость мутанта rib80 rib 1-86 позволила легко ввести в его геном трстью мутацию - rib81 за счет отбора спонтанных РФ-независимых ревертантов. Тройної мутант LV172-2 (прототроф по РФ), как и шптамм rib81 rib/-86, неспособен к сверхсинтсзу РФ в условияк дефицита железа, т. е. иутация rib80 в этом случае не усиливает влияния мутации rib81 на биосинтез РФ (см. таблицу).

Таким образом, выделсн регуляторный мутант $P$. gulliermondii с поврежденным геном $R / B t, y$ которого мутация локализована, очевидио, в промоторной золе этого гена. Об этом свидстельствует полная ауксотј;офность мутанта LVI66 по РФ и высокая специфинность супрессии потребности в РФ под влиянием мутации rib81, но не таковой rib80 или дефицита железа в среде.

Можно предположить, что мутация rib1-86 приводит к нарушению взаимодействия факторов позитивного типа дсйствия (продуктов генов $R I B 83, R I B 84$ или других, пока не идентифицированных) с их акцепторными сайтами в промоторной зоне гена RIBI. У мутантов ribl-86 продукт гена $R I B 81$, являющийся, очевидно, репрессором, полностью подавляет экспрессию структурного гена ГТФ-циклогидролазы, так как мутация rib81 частично восстанавливаст синтез этого фермента.

Важно отметить, что у мутантов rib81 rib1-86 дефицит жкелеза не вызывает дерепрессии активности ГТФ-циклогидролазы и, как следствие, сверхсинтеза РФ. Из этого вытекает, что мутация rib1-86 нарушает механизм регуляции синтеза ГТФ-циклогидролазы, в котором участвует железо.

Приведенные данные свидетельствуют о том, что механизмы регуляции синтеза ферментов флавиногенеза у дрожжей являются значительно более сложными по сравнению с таковыми у бактерий. Қак известно, у Bacillus subtilis в регуляции транскрилции РФ-оперона участвует ген-регулятор ribC и оператор ribO [9] .

Очевидно, мутант ribl-86 P. guilliermondii является удобной моделью для изучения взаимодействия различных регуляторных сигналов, участвующих в контроле биосинтеза ферментов флавиногенеза, путем конструирования штаммов, несущих несколько регуляторных мутаций. Клонирование гена RIBI P. guilliermondii [10] открывает возможность более глубокого изучения структуры регуляторных сайтов промотора этого гена.

P е 3 ю $\mathrm{M} \mathrm{e}$

y роботі селекціонований мутант rib1-86 P. guilliermondii, у якого рибофлавінзалежність супресується регуляторною мутацією rib81, aле не rib80. Подвійний мутант ribl- $\delta 6$ rib81 характеризується юизьким рівнем активності ГТФ-циклогідролази, синтез якої слабо регулюється залізом. Очевидно, мутація ribl-86 лежить в промоторній області гену $R I B I$, що кодує ГТФ-циклогідролазу. 
The rib $1-86$ mutant of $P$. guilliermondii in which riboflavin allxotrophy is suppressed by mutation ribs 8 , but not by rib80 was selected. Double rib 1.86 rib 81 mutant is characterized by low GTP-cyclohydrolase activity. The enzyme synthesis is faintly regulated by iron. It is supposed that rib/.86 mutation is localized in the piomolei region of RIBI gene which codes for GTP-cyclohydrolase.

\section{СПИСОК ЛИТЕРАТУРЫ}

1. Buteneнue и характеристика флавиногенных штаммов Pichia guilliërnondii, несущих perуляторную мутацию ribso/ribR/ Г. М. Шавловский, Д. В. Федорович, Е. М. Логвиненк, П. В. Колтун // Микробиология.-1985.-54, № 6.- С. 919-926.

2. Генетический контроль биосинтеза рибофлавина у дрожжей Pichia guilliermondii. Обиаружение нового регуляторного гена rib81/Г. М. Шавловский, Л. Л. Бабяк, А. А. Сибирный, Е. М. Логвиненко // Генетика.- 1985.-21, № 3.-С. 368-371.

3. Pегляяия биосинтеза рибофлавина элемештами позитнвного контроля у дрожжей Pichia guilliermondii/ Г. М. Шавловский, Л. В. Колтун, Б. В. Кшановская и др. // Там же.- 1987.-- 25, № 2.- C. 250-258.

4. Guarente l. Regulatory proteins in yeast// Annu. Rev. Genet.-1987.-21.P. $425-452$.

5. Генетическая классификация рибофлавинзависимых мутантов дрожжей Pichia guilliermondii / Г. М. Шавловский, А. А. Сибирный, Б. В. Кшановская и др. $/ /$ Генети ка. - 1979.-15, № 9.- C. $1561-1568$

6. Waring W. S., Werkman $C$. II. Grouth of bacteria in iron-free medium//Arch. Biochem.- 1943.-4, N 2.- P. 303-310.

7. Влияние железа, актиномицица D и циклогексимида на синтез рибофлавинсинтазы у флавиногенных дрожжей / Е. М. Логвиненко, Г. М. Шавловский, А. Е. Закальский, И. В. Заходило // Биохимня.- 1982.-47, № 1.-С. $28-33$.

8. Исследование роли флавинов в регуляции синтеза рибофлавинсинтазы у дрожжей Pichia guilliermondii и Candida utilis/Е. M. Логвиненко, Г. М. Шавловский, В. М. Трач, А. А. Сибирный // Микробиология.-1973.-42, № 6.- С. 1008-1013.

9. Oперонная организация генов биосинтеза рибофлавина Bacillus subtilis / B. M. Mирогов, М. Л. Чикиндас, А. С. Краев и др. // Докл. АН СССР.- $1990 .-312$, № 1.С. $237-240$.

10. Клонирование гена RIBI, кодирующего фермент первого этапа флавиногенеза дрожжей Pichia guiliermondii-ГТФ-циклогидролазу, в клетках Escherichia coli/ А. Е. Закальский, М. Л. Злочевский, Ю. З. Стасив и др.// Генетика.- 1990.- 26, № 4.- С. $614-620$.

Львов. отд-ние Ин-та биохимии им. А. В. ГІалладина AH YCCP

Получено 15.03 .91 